\title{
DRY FUEL FORESTS OF THE MADRAS PROVINCE
}

A SMALL illustrated monograph written by Mr. A. L. Griffith, I.F.S.* provincial sylviculturist, Madras, merits the close attention of the administrative and forest officers in West and East Africa.

A century ago in the 1830's and 1840's Madras was passing through some regrettable and painful forestry experiences. The administration for four decades had had no belief in the necessity of a forest policy or in forest protection ; and the people naturally wanted neither. Whilst, therefore, during the first half of the nineteenth century the finest teak forests or the most accessible at that time were despoiled, the larger areas of forest situated in the central and eastern regions - what are termed here the dry fuel forests (savannah or bush in Africa) -were regarded as of no value and the population allowed to cut, burn and overgraze them, as in the past. Even when the Government realized that some form of protection should be given these areas, they were not regarded as 'forests' or placed under the then existing Forest Department. The idea grew and persisted that the work of the forest officer should be confined to the management of marketable timber forests onlyan idea which has resulted in irretrievable harm to much forest and has caused the disappearance of large areas both of 'timber forest' and 'dry fuel' or 'bush' forests. Mr. Griffith writes : "The dry fuel forests of the unreserved, waste lands and panchayat forest" (in which the administration at one period placed such a childish faith) "have either completely disappeared or are very rapidly disappearing due to the ravages of man and his animals, chiefly goats." Some of Mr. Griffith's predecessors were writing nearly identical words almost exactly a century ago; the country, be it remembered, being at that period much less developed and the population and their animals very much less numerous.

At the present day we are told that the dry fuel forests of Madras are one of the most important types

* "Note on the Artificial Regeneration of the Dry Fuel Forests of the Madras Province" (Ind. For. Rec., Silvic. (New Series), 3, No. 8. New Delhi, Govt. of India Press : 1940). occurring in the Province, and in reserved forest alone they consist of roughly 900,000 acres with an annual cut of approximately 30,000 acres which produces an annual revenue of Rs.400,000. This type, says the author, occurs in twenty-two out of twenty-eight districts, and the general climate has an average rainfall of from 10 to $35 \mathrm{in}$., most of this precipitation coming from the north-east monsoon in October and November. Apart from this rainy period the rest of the year is generally very dry and very hot. These forests are essentially 'local' forests, and supply the needs of the local villages with fuel, agricultural implements, small building timber, grazing, etc.

What is the difference between this 'type' and that of the large areas of so-called savannah or bush in Africa, upon which the people equally depend in one way or another for the chief ingredients of existence? Yet in Africa, by many of the administration at least -and probably not a few forest officers (all brought up in the belief) - savannah or bush was until quite recently not regarded as forest or as meriting or requiring any attention. That the recognition of the value of the type took upwards of a century in Madras is surely no reason for wasting so long a period and making the same mistakes in Africa. The following brief extract from the monograph, which must be read to be fully appreciated, may be considered :"These areas which are in the reserved forests are worked in general on a thirty-year rotation, now in many cases being raised to forty years, by the system of simple coppice. At each coppicing the mortality of stools is 5-10 per cent and this is not being replaced by natural regeneration.

"Hence the improvement and maintenance of these forests by artificial regeneration is an absolute necessity" (italies are the author's).

During the past ten years it has been shown that this artificial regeneration can be done with a certainty of success and at a reasonable cost even under the poorest conditions by the 'rab' method, and at practically no cost at all by the 'rab-kumri' method, that is in conjunction with field crops (shifting cultivation).

\section{STEAM HEATING OF BUILDINGS}

$\mathrm{S}^{\mathrm{a}}$ long ago as 1653, Sir Hugh Plat, of London, heated glasshouses with steam from a cast-iron pot placed outside. This is described in his book on horticulture, "The Garden of Eden". James Watt is believed to have used in 1784 the first elementary steam radiator. It was fitted in his study and consisted of an iron box with connecting pipes through which steam was passed from boilers. In 1825, Matthew Murray, of Leeds, the well-known competitor of James Watt, heated his house, which was locally known as "Steam Hall", by means of exhaust steam from the engine of his adjoining works. Meanwhile, in 1804, Oliver Evans in the United States had mentioned in one of his patents the use of exhaust steam from engines for heating.

An interesting article by David Brownlie, which deals specially with steam heating in the United States- begins in Engineering of September 5. $\mathrm{He}$ points out that from the technical and scientific point of view, one of the most serious defects of modern civilization lies in the fact that the condensing steam engine and turbine still lose some 55 per cent of the total heat in the coal, or other fuel, in the condenser. Even more serious is the use of the noncondensing engine, of which a particularly bad example is the steam locomotive operating at a thermal efficiency of no more than 6-8 per cent. Now experience with thousands of plants, mostly relatively small, has shown that great economy in fuel can be obtained by employing back-pressure or pass-out engines and turbines and utilizing the exhaust steam for heating and process work. The actual thermal 